Las Torres de Lucca. Revista internacional de filosofía política

ISSN-e: 2255-3827

\title{
What is Left for Critique? On the Perils of Innocence in Neoliberal Times ${ }^{1}$
}

\author{
Paulo Ravecca ${ }^{2}$; Elizabeth Dauphinee ${ }^{3}$
}

Recibido: 16-01-2020 / Aceptado: 2-7-2021/ Publicado: 30-01-2022

\begin{abstract}
This essay explores the implications of what we call attachments to innocence for scholarship and politics. After tracing the appearance of innocence in various strands of contemporary thought, we turn to how it shields individuals and groups from facing the depth of our own participation in oppression. This evasion of responsibility works in our perspective as a hindrance to understanding power and engaging with others ethically. The essay also examines how the reductionist and authoritarian dimensions of innocence merge with the neoliberal uptake of progressive politics in university and activist settings. We are interested in how academics and activists are rewarded for cultivating their innocent-selves through discursive and material interventions that leave power relations untouched. It is not merely monetary or status rewards that perpetuate this, but the crisis produced by our implication in the very violence we reject. Working with and through the mobility of agency, power, abuse, and justice, we explore what is at stake in shedding our attachments to innocence in the hope of a different sort of encounter - one that proceeds from the recognition that innocence is not a precondition for our engagement in political life.
\end{abstract}

Keywords: Attachments to Innocence; Neoliberalism; Radical and Progressive Politics; University; Reflexivity.

\section{[en] ¿Qué queda para la crítica? Sobre los peligros de la inocencia en tiempos neoliberales}

Resumen. Este artículo explora las implicaciones para la academia y la política de lo que llamamos apegos a la inocencia. Luego de rastrear las formas en que la inocencia aparece en diferentes corrientes del pensamiento contemporáneo, nos concentramos en cómo ella protege a individuos y grupos de confrontar nuestra profunda participación en la opresión. Esta evasión de la responsabilidad funciona, en nuestra perspectiva, como un obstáculo para comprender el poder e interactuar éticamente. El artículo también examina cómo las dimensiones reduccionistas y autoritarias de la inocencia se fusionan con la apropiación neoliberal de la política progresista en la academia y el activismo. Nos interesan los modos en que académicos y activistas son recompensados por cultivar un yo-inocente a través de intervenciones discursivas y materiales que mantienen intocadas las relaciones de poder. No son las recompensas meramente monetarias o de estatus las que perpetúan esto, sino la crisis que produce nuestra implicación personal y colectiva en la violencia que supuestamente rechazamos. Trabajando con y a través del carácter móvil de la agencia, el poder, el abuso y la justicia, exploramos qué está en juego a la hora de poder, o no, superar los apegos a la inocencia. Hacemos esto con la esperanza de delinear otro tipo de encuentro: uno que procede del reconocimiento de que la inocencia no es una condición para nuestra participación en la vida política. Palabras clave: apegos a la inocencia; neoliberalismo; política progresista y radical; universidad; reflexividad.

Cómo citar: Cómo citar: Ravecca, P. y Dauphinee, E. (2022). What is Left for Critique? On the Perils of Innocence in Neoliberal Times. Las Torres de Lucca. Revista internacional de filosofía política, 11(1), 37-49. https://dx.doi.org/10.5209/1tdl.77064

This paper explores what we call attachments to innocence and their implications for ethics and politics. These attachments seem to be a central feature of contemporary life both in the academy and in society at large. Our argument is that looking at the world through the prism of innocence entails a series of moves that obliterate complexity and lead towards perilous forms of simplification and dogmatism. Such moves include the policing of strict intellectual and moral boundaries between oppressors and oppressed, the fixity of victims and perpetrators, and the reliance on moral goodness as the foundation for action. Furthermore,

\footnotetext{
We gratefully acknowledge the feedback and suggestions of Terrell Carver, Naeem Inayatullah and two anonymous reviewers. Errors and omissions remain the responsibility of the authors.

Agradecemos los comentarios y sugerencias de Terrell Carver, Naeem Inayatullah y dos evaluadores anónimos. Posibles errores y omisiones son nuestra responsabilidad.
}

2 Paulo Ravecca, Universidad de la República.

Email: paulo.ravecca@cienciassociales.edu.uy.

ORCID: https://orcid.org/0000-0002-9754-9520

3 Elizabeth Dauphinee, York University.

Email: dauphine@yorku.ca

ORCID: https://orcid.org/0000-0002-2925-4376

Las Torres de Lucca. 11 (1), 2022: 37-49 
contemporary attachments to innocence are intertwined with the operations of neoliberalism and neoliberal institutions, which absorb and incorporate projects of reform, or even radical interventions, in a variety of depoliticizing ways.

We are interested in how attachments to innocence work to obscure the multiple registers on which oppression and violence operate. In other words, in how they prevent reflexivity (Amoureux \& Steele, 2016) from becoming anything more than a rubric. We argue that the unproblematized appearance of goodness and purity that accompany progressive politics and marginal positions works paradoxically very well with the neoliberal mandate for moral self-promotion in marketized settings. Taking a glance at social media feeds seems enough to see how liberals and radicals make sure that their being-on-the-right-side-of-history is carefully and publicly registered into both formal and informal CVs. We are not suggesting in any way that conservatives and right-wingers lack attachments to innocence. However, we are suggesting that our critique is especially relevant for leftists precisely because such attachments might undermine the commitment to social justice in important and powerful ways. The counterpart of this is the contamination, guilt, and anxiety that are left as the uncomfortable remainder that must be denied and avoided.

The circulation of innocence in culture, philosophy, and religion runs deep (Johnson, 1988; Ticktin, 2017; Rothberg, 2019). Innocence both precedes and exceeds its current appearance in neoliberalism, but it does carry implications that are specific to the neoliberal context. While the critiques of neoliberalism (Amadae, 2016; Brown, 2015; Harvey, 2005; Menéndez-Carrión, 2015; Saad-Filho \& Johnston, 2005) and of the neoliberal university (Bourdieu, 1988, Giroux, 2003; Mohanty, 2013, etc.) are well-established, less closely examined is how attachments to innocence operate within the institutional and social environments increasingly engulfed by neoliberal rules of engagement and metrics of success or viability.

We do not offer a complete theorization of innocence in political or intellectual life. Rather, we try to trace conceptually how we see innocence working, and particularly how it shields us from examining the depth of our own complicity in oppression, which we think is a hindrance to understanding power and engaging with others ethically. Our complicity is not a caveat that - like other acknowledgements - can be stated and forgotten. With Gramsci (2008, p. 324), we recognize that "the starting point of critical elaboration is the consciousness of what one really is, and is 'knowing thyself' as a product of the historical process to date which has deposited in you an infinity of traces, without leaving an inventory." We also recognize that complete transparency to ourselves is impossible (Rossello, 2019; Ravecca \& Dauphinee, 2018). Our complicity is not just a starting point, then, but a constant presence in critical thought and analysis that bears returning to again and again.

We undertake this exploration of what is at stake in shedding our attachments to innocence in the hope of a different sort of encounter - one that tries to uncover and work through our unavoidable complicity in structures of oppression. Thus, the article concludes by looking at the encounter as an opportunity through which we might seriously grapple with our attachments to innocence.

\section{Contemporary Attachments to Innocence}

Suffering in the world, and the persistent inability of political actors and elites to do anything about it - or, worse, their overt involvement in its root causes - offer an important motivation for political and social activism and for critical intellectual projects alike. These motivations are geared toward correcting contemporary inequities and in redressing the historical injustices that exist in virtually all aspects of our societies. The pervasiveness of such injustice, however, is engulfing and therefore generates moral anxiety or even ethical injury (Sky, 2015). Accordingly, "in the contemporary era," writes Miriam Ticktin (2017, p. 578),

we are embroiled in a search for a space of purity, a space outside corruption and contamination, a space emptied of the power that can ground both tolerance and action; innocence provides us with such a conceptual space. Yet, because innocence is both mythical and ephemeral, we are constantly displacing politics toward the limit of innocence in a never-ending quest.

Here, Ticktin points to part of the problem that we wish to examine - the way that innocence is mobilized to frame and delineate the possibilities for politics. However, we add to this that, from our perspective, the performance of innocence is indeed a form of the exercise of power in our contemporaneity.

Following Johnson (1988) we understand innocence as an active comportment or orientation that needs to be reproduced, rather than a state of being or an attribute. Innocence, Johnson writes $(1988$, p. 9), is not merely "the absence of blameable features or particular guilt, but...the presence of a particular kind of moral disposition" that can be traced and examined for its appearance in social and political life. An examination of this disposition will allow us to appreciate how innocence is both active and reproductive, a praxis that is - like all praxes - actively conditioned by the power relations within which it flourishes.

For Hannah Arendt and for scholars like Johnson (1988) and Wolgast (1993), innocence in the political sphere is dangerous because it requires a kind of purity that is actually inadequate for the exercise of morality. 
In order to engage morally, a person must be aware of the possibility of doing evil - they must be aware of the possibility of making an immoral choice and the consequences that might flow from this. Innocence relies on a certain ignorance - a commitment to not knowing that shields the innocent from the very possibility of discerning evil. The concern with the maintenance of purity and innocence is important here. For Ticktin (2017, p. 578), the relation between innocence and purity unfolds across several different, but obviously related, registers. "Innocence," she writes, "works to regulate a space of purity: sometimes this means to be without knowledge, sometimes to be without intention, sometimes to be free from desire, and sometimes free from guilt." While she identifies states that are characterized as "freedom(s) from," Ticktin also clarifies that innocence, in its many forms, is regulatory. We can suggest that this regulation also performs a disciplinary function that is seen and felt in the reproductive practices of innocence. The political categorizations associated with innocence cannot exit the landscape they denounce. Ticktin, for example, points to victimhood and innocence as a nearly interchangeable concepts, noting, for example that "the phrase innocent victim occurs so often that it can be difficult to think of innocent and victim apart" in sociopolitical life (p. 587). Wendy Brown (1995) also points out that the expression of injury as the motivation for politics ties the subject to a particular conception of engagement that limits the politics of emancipation that critical thought and action are trying to enact.

The erasure of agency that accompanies innocence offers an image of powerlessness and of the powerless as in need of protection. Such erasure is embedded in the contemporary political world where we enter as subjects who are both implicated in processes of oppression and who are curiously framed as powerless to do anything about them (Brown 1995). For Brown, the injury emerges as a site of politics in a way that limits the horizons of freedom. ${ }^{4}$ As Brown puts it, the

critique of power from the perspective of the injured...delimits a specific site of blame for suffering by constituting sovereign subjects and events as responsible for the "injury" of social subordination. It fixes the identities of the injured and the injuring as social positions, and codifies as well the meanings of their actions against all possibilities of indeterminacy, ambiguity, and struggle for resignification and repositioning (1995, p. 27).

This injury-centered politics ends up reducing the injured to their injuries, curating a political environment of powerlessness, bitterness, and resentment. Novelist, playwright, and Pulitzer Prize winner Ayad Akhtar refers to "the tidal wash of ubiquitous and ascendant anger" attached to current politics of representation in the US (Akhtar, 2020, p. 265). In our view, injury, resentment, and innocence share a sticky conceptual intimacy where mutual translations permeate their expression of the political. For Ticktin (p. 583), "a politics based on innocence requires not only the search for but also the production of innocent victims, since the 'pure' victim is a placeholder, always just out of reach." Accounts of the world that rely on the need to identify innocence leave little space for contestation and reflection.

Two consequences flow from this that we want to think about - the first is the foreclosure of politics through reification. The fixation in the wounds obscures the indeterminacy and polyvalence of human encounters and severs the edifying bonds between progressive politics and the constant struggle for freedom (Davis, 2016). The second consequence, which we want to understand more about, occurs in the re-politicization of innocence as a space where our own complicity in oppression is either purified or denied altogether. The dichotomy between injured and injurer approximates the distance between good and evil. In our interpretation, injury, like victimhood and other proxies for purity (Ticktin, 2017), acts as a vector for innocence and serves as an obstacle to unpacking power relations (i.e., the practice of reflexivity). We are shielded by our proximity to injury and victimhood, either as those who experience these or as those who are on the side of the sufferer. Our goodness becomes a crucible within which various forms of oppression continue to flourish, unobserved. As Peter Johnson (1988, p. 15) puts it, "the virtues of the morally innocent are absolute and it is only on this basis that we can fully understand their character and the dilemmas they encounter" in the world.

Its simplicity and absolutism implicate innocence in processes that we would normally recognize as totalitarian (Arendt, p. 1993), such as depoliticization, political homogenization, and ideological closure. We agree with Arendt that what is lacking in moral innocence is the capacity to "persuade, argue, and reason with others in a public world" (in Johnson, p. 163). Innocence appears in the public realm as a moralizing goodness. When we consider this absolutist character of innocence in conjunction with Johnson's (1988, p. 10) observation that "innocence as moral purity implies an inability to inflict harm," we find a goodness that seems to require no further examination. The range of relations available to us from this location are stark and binary: good/evil, victim/perpetrator, injured/injurer, innocent/guilty. We are motivated in such an arrangement to locate oppression and violence outside, while securing our own engagements as somehow different from others'. This quest becomes self-referential. It blocks us from imagining our own complicity in processes of oppression and violence, obscuring how power works and how we move within its landscapes. Innocence, we

Brown is writing in the US context, but the problems that she identifies in the liberal and rights-based political formation are to varying degrees transposable to other democratic contexts (see also Ticktin, 2017, who notes the geographic and political plurality of notions of morality). 
could say building from some of Marquis de Sade and Friedrich Nietzsche's oeuvres and revulsive insights, is a form of violence; the trope of innocence allows us to actualize and become while avoiding the immanent and unavoidable horror of that journey - and the violence, dispossession, and displacement that accompany it (Nietzsche, 2007; 1990; Sade, 1996).

Attachments to innocence shift and change throughout history, as do the philosophical suspicions they inspire. Marx's exploration of how liberalism's apparently virtuous championship of human freedom was in in reality deeply embedded in capitalist exploitation stands out in this regard, and it was taken in different directions that include, but are not exhausted by, contemporary assessments of neoliberalism (Brown, 1995; 2015; Harvey, 2005; Losurdo, 2011; McNally, 2011). We briefly situate liberalism under the spotlight because of its capacity to monopolize all seemingly reasonable discussions (Nicolacopoulos, 2008 , p. 4) and its proclivity to being equated with goodness in politics; and, also, because we observe that contemporary liberal politics and its establishment reveal many sites where attachments to innocence are forged or maintained. In Amadae (2016)'s view, the mutations from liberalism to neoliberalism have implied a normative debilitation of social arrangements. We are interested in how the attachment to innocence operates within this conceptual landscape.

A timely example lies in the incensed attacks on populism, which are performed through entreaties to both morality and science as ways of narrowing the scope of political decisions, identifying the so-called extremes of left and right as unreasonable. This is particularly pervasive in the media but also appears in the interventions by scholars in respected outlets and journalistic TV programs. Technical and scholarly knowledge sanctions some artifacts of our contemporaneity (such as globalization, the free market, and technological progress) as self-evidently good, while routinely coupling these artifacts with the normatively unsurpassable notion of human rights. Other positions are externalized as unviable or dangerous (nationalism, populism, socialism, communism and so on) precisely because they are identified as exterior vis-à-vis the realm of such rights. In an interesting mélange of positivist objectivity and moralizing accounts, respectable officialdoms tend to erase the participation of both academia and the leaders of the "free world" in the making of the oppressive conditions that are behind, among other political processes, the emergence of the radical right throughout the world. Furthermore, the consolidation of strategic rationality as the hegemonic form of rationality exacerbates the powerlessness of the calls to be moral or ethical. It is far from surprising that attachments to innocence and metrics of victimhood are frequently internalized as comparative advantage into rational (i.e., individualistic) strategies for building pathways in the different competitive markets (activist, scholarly or corporate) we inhabit.

Recognizing this universality of oppression does not negate the critical importance of its particularities of place and context, nor do we suggest that all oppressions and responsibilities are equal. But if oppression can come from unexpected places (Ravecca 2019, p. 187) looking at innocence and the attachments to it from this perspective strikes us as both challenging and necessary.

Since the Frankfurt School, scholarly objectivity and its embeddedness in social domination remain a usual target for critical theorists (Horkheimer, 1978; Marcuse, 1991). ${ }^{5}$ However, critical theory's commitment with justice makes it particularly vulnerable to attachments to innocence and their ethical lacunae. The struggles to maintain innocence and goodness find in the neoliberal university many pathways - sometimes blended with positivism, sometimes militantly distinct from it - through which the self can seek exoneration - for example, social activism, writing transformative texts, engaging in radical politics, and speaking truth to power. These commitments help us to avoid the pain, which is not merely that neoliberalism causes harm, but that it is our own investments that perpetuate this oppressive system. Yet, in some way, it must also be up to us to end this thing that we rely on so intimately (Kurowska, 2020). Put simply, there is great need to hide our own complicity from ourselves and one another. There is a need to hide the rewards of violence. Innocence, we submit, is therefore also a hiding place - a fortress where we can believe that we are resisting neoliberalism even as our work and the structures we operate in sustain the power of that very relation. It takes seconds of glancing at how scholars usually frame ourselves in our online profiles to see this... the unrelenting display of scholarly merits, impact factors, number of publications, won and declined scholarships, self-definitions as leading critical thinkers. Think also of the exorbitant fees charged by some world leading critical theorists to share their social justice views with students, colleagues, and activists. The blindness of tacky and noisy meritocracy, with its sneaky and corrosive mergence between prestige, global power, and performance of criticality permeates the radical sites of the scholarly world. ${ }^{6}$

Referring to Lynne Layton's notion of one eye seeing and one eye blind, Kurowska writes that the academic proceeds "simultaneously knowing and not knowing about the implications at play in furthering one's own and each other's neoliberal suffering" (29). This not-knowing allows us to enjoy the pleasures (or the promise) of status and privilege while simultaneously denouncing this in others. This is not always and only reducible to hypocrisy, but instead gestures to a Janus-faced state (Kurowska 2020, p. 30) that is nurtured by the neoliberal

Ravecca (2019) offers an overview of different strands of critical theory, their frictions, and points of connection.

For an extensive critique of meritocracy see Sandel (2020). 
academy's uptake and reproduction of the social justice orientation of critical scholars, and is tied to its need to remain relevant in a society obsessed with metrics and hands-on relevance.

This has also led to a growing industry in community engagement and experiential learning in universities, with its concomitant concern with knowledge mobilization and impact. Academics are increasingly expected to perform activism. As Laura Shepherd $(2017,46)$ shows, "the subject now emerging from discourses about performance, relevance, and impact, is an activist-scientist subject, and more besides. She is expert, authority, knowledge, yet the conditions of her possibility are restlessness, inadequacy, loneliness, and fear." She writes that the contemporary university's commitment to engagement, impact, and knowledge transfer,

are ideas that have become commonplace in the neoliberal academy. I saw "activism" as one more pressure, one more underdeveloped dimension of my professional self, one more way to fail to meet the expectations others held... [The modern university evinces the] expectation that activism - or at the very least "social engagement" - will be integrated into our work product, as part of our quotidian "responsibilities" (p. 52).

Shepherd's portrait is illustrative here, not only because it illuminates the pressures on academics to perform a particular brand of engagement, but also because it highlights the ultimately instrumental and hollowed-out nature of what that engagement means. She shows how activist scholars must take up both the mantle of truth and the ethos of utilitarianism in order to be relevant and valued at a historical juncture that despises uncertainty, paradox, hermeneutics, and complexity. We add that even the language of poststructuralism can be codified into efficient, quick, and seemingly useful interventions that, as such, are easily saleable and riskfree - after all Foucault (1991) himself warned of the polyvalence of any fragment of discourse and this does not exclude references to poststructuralism itself.

In this current neoliberal context (Amadae, 2016; Brown, 2015; Harvey, 2005), the pursuit of innocence and goodness connects easily with the dynamics of branding, and of moral, intellectual, and political selfpromotion. This is a terrain that, for all its documented anxieties, also offers the deep emotional reward of "doing good" while never having to confront the reality that violence, exclusion, and oppression are carrying on just as they were before. This is not about one's scholarship or activism being ineffectual, but about the (real or promised) emotional, economic, and status benefits that accrue to our own oppressive practices.

This phenomenon is not relegated to academic environments. Activisms of all stripes are also perforated by neoliberal imperatives around self-promotion and metrics of individual success. Patrisse Khan-Cullors and Asha Bandele (2018, p. 219) point to the invisibility of those who are not able to "sharpen and hone their personal brand so that it is an easily sellable commodity." It is not difficult to see how doing good in neoliberalized landscapes produces what can be called moral capital accumulation for the doer, particularly in a world where visibility and exposure of the self in social media have become crucial (We are social and Hootsuite, 2020b). As Neoliberalism has become our natural(-ized) Weltanschauung - a worldview that is, as Menéndez-Carrión (2015) says, so confident in itself that does not need to be argued for - it has infiltrated the regulation of how we curate ourselves as critical, progressive, or radical. We believe this is of the utmost importance and an aspect in which radical hesitation and immanent critique (Stahl, 2013) need to be introduced. And a way of doing so is precisely interrupting the confidence in our attachments to innocence. In a world shaped by violence and inequality there is no room for the purity innocence claims for itself.

This problem transcends the common critique of NGO-ization or professionalization of social movements and points to a more profound leitmotif that encompasses both politics and ethics in our contemporaneity: that the very political and politicizing activisms possess, in their performance of innocence, a depoliticizing blind spot that welcomes the (neoliberal) rules of engagement that are supposed to be the target of deep examination and critique. As Kurowska (2020, p. 38) puts it, "self-realization, intellectual and normative, is pleasurable. But by doing so we, mostly inadvertently or perhaps unconsciously, reproduce the system of suffering."

The movement of innocence depoliticizes the power relations that both circumscribe and enable it. This depoliticization is part of the way that neoliberalism coopts, transforms, and redeploys resistance as a nonthreatening commodity to be marketed to attract both institutional funding and, in the case of universities, students looking for the experience of having impact in the world. We find an interesting parallel here with Brown's point regarding resistance and empowerment in liberalism. She writes:

contemporary discourses of empowerment partake strongly of liberal solipsism-the radical decontextualization of the subject characteristic of liberal discourse that is key to the fictional sovereign individualism of liberalism. Moreover, in its almost exclusive focus on subjects' emotional bearing and self-regard, empowerment is a formulation that converges with a regime's own legitimacy needs in masking the power of the regime (...) the possibility that one can 'feel empowered' without being so forms an important element of legitimacy for the antidemocratic dimensions of liberalism. (1995, p. 23).

Academic institutions are important sites where politics of representation orbit around attachments to innocence. As Chandra Mohanty (2013, p. 972) puts it, "the interwoven processes of privatization, consumption, 
and commodification of theory result in a politics of representation or a politics of presence disconnected from the power and political economy of rule." This allows for a praxis of depoliticized diversity in which quotas and thresholds are appended to bodies and ideological commitments are mostly left untouched or else are confronted in a rhetorical, non threatening way. These "rhetorical commitments" (p. 972) do not threaten power relations. More than this, they also actively participate in the co-optation of radical approaches in order to depoliticize and domesticate them. Mohanty (2013, p. 971) asks: "what happens to the key feminist construct of 'the personal is political' when the political (the collective public domain of politics) is reduced to the personal?" Political agency is transformed into an act of consumption, and diversity is reduced to a "managerial discourse," rather than reflective of the "discordant realities" around gender and racial justice (p. 974). This reduces diversity to demographics, leaving ideological formations untouched. Once positionality is equated to demographics, the space of engagement and critique becomes extremely narrow. A Bolivian individual with Aymara background trained at an elite institution in the global North may make the tenuretrack shortlist as a diverse candidate. But if trained at a Bolivian institution, such a candidate would hardly garner any serious notice. That is a loss in knowledge, and it is also unfair. While celebrated or even defended, diversity is codified in ways that do not threaten the fundamental structures of inequality and power.

Marxist scholarship reproduces itself in this way as well. The fusion between modernity and liberalism (Brown, 1995) has disconnected Marxism from the motions of the social and of academia, which, as any other human activity in the sense of Marx (1978), is embedded in its social conditions. Something missed in Keucheyan (2016)'s assessment of critical theory is that, in the era of neoliberalism, Marxist scholarship works as any other identity or brand. The capitalistic materiality of academia engulfs and neutralizes radical intentions which then become part of the portfolio and the dossier for tenure. The languages that these mechanics mobilize (postmodern, Marxist, critical) do not really matter that much. They are equally absorbed by an epidermic brand war between theories and styles of scholarship.

The duplicity at the core of these dynamics is nerve-wracking and undermines the conditions of possibility for carefully crafted thoughts and fruitful engagements with complexity and uncertainty. In fact, such an environment infuses a kind of dogmatic and speedy shallowness into radical views of different kinds. Indictment displaces critique. Listening is equated to weakness. What can be done when the vocabularies of liberation and even their tools and tactics work in this profoundly contradictory and even deceptive way?

The idioms of emancipation are frequently mobilized to defeat others in particularized discussions linked to the advancement of one's professional reputation or career trajectory, or to the allocation of specific resources within and between university departments - and NGOs, unions, state institutions, and so on (Slaughter and Leslie, 1997). In the context of the neoliberal capitalist economy that engulfs most of us in one way or another, this deception lies at the heart of our need to establish and defend our innocence; that we could free ourselves of these entanglements, that we are expected to, but when we examine our entanglements with power we find that we cannot. Deep down we know this and the fraudulent condition we inhabit generates a malaise that feeds into the politics of innocence but at the same time reveals the authoritarian violence of innocence's gestures. Outrage, bitterness, and dogmatism are troubling and troubled venues in which attachments to innocence manifest. They seem to be a failed attempt to distract us from the knowledge that deceit is woven into the fabric of our condition.

Progressive ideals are mobilized as resources, as commodities in the market whose transactions increasingly incorporate social responsibility, diversity, justice and so on. Corporations perform these metrics through an orientation towards purpose $e^{7}$ or even more ambitiously through ingenuities such as conscious capitalism; ${ }^{8}$ the state through the allocation of "rights;" and academics (in best cases) by becoming activist scholars who lead students through the experiential landscapes of the marginalized as "real world" education. Of course, the meaning of this in neoliberalized milieus is specific and depoliticizing. In the case of academia, it is designed to attract students with the promise of an education that is relevant to the nomadic urban landscapes they will have to occupy. The fundamental challenge against neoliberalism does not happen.

Coupled with how it is taken up in institutions, the attachment to innocence and goodness works in our perspective as an epistemological and political blockage to a genuine examination of our individual and collective circumstances and the ways in which, through our own practices, we are involved in (and to different degrees benefit from) oppression and inequality. This involvement is not about a pre-given and reified attribute (expressed in our bodies, titles, wealth, and so on); collapsing positionality and demographics, for example, produces the same kind of reductionism that in part motivates the writing of this essay, and that we find in our examination of innocence, particularly around predefined responsibilities and categories of guilt and innocence, or victim and perpetrator. Further, not being able to see our complicity as something more profound than a mere caveat reduces it to a tragic inevitability whose managed incorporation is the only other available option. The encounter with complicity on a landscape of such limited political possibility is reducible to

The "Statement on the Purpose of a Corporation" published by The Business Roundtable, a collection of CEOs from the most powerful corporations in the US, epitomizes this trend. See https://opportunity.businessroundtable.org/wp-content/uploads/2020/04/BRT-Statement-on-the-Purpose-of-a-Corporation-with-Signatures-Updated-April-2020.pdf

See https://www.consciouscapitalism.org/ 
being "bad," "oppressive," or "contaminated." Yet stepping into action to guard, or achieve, the purity of our intentions does not evade the critique.

Sometimes, through acts of liberation, we end up undoing the horizon of freedom we claim to be building. As Arendt put it:

Every good action for the sake of a bad end actually adds to the world a portion of goodness; every bad action for the sake of a good end actually adds to the world a portion of badness. In other words, whereas for doing and producing ends are totally dominant over means, just the opposite is true for acting: the means are always the decisive factor (Arendt cited in Johnson, 1988, p. 160).

Putting aside Arendt's controversial categorical distinction that starkly separates reproduction, production, and action (Arendt,1995), hers is an important observation, because it decouples impact from intent, and it complexifies the processes through which we could come to understand something as good or bad, oppressive or emancipatory. For this reason, we also follow Uruguayan thinker Carlos Real de Azúa (1973) in his observation that liberations need to be interpellated by their own partiality to guard against their becoming oppressive themselves, a point we have raised before and that we think bears repeating (Ravecca \& Dauphinee, 2018).

\section{Stepping Beyond Innocence}

If the art of critique is tied to intervening in the world in ways that open possibilities for the future, how do we undo the constraints that bound so many of our encounters? We would like to offer a conceptual starting place: in a world of shared inequality and oppression, we do not need to establish our innocence in order to be worthy of our liberation. Recognizing the inescapable depths of our complicity in oppression - even the criminal aspects of our lives - is not about identifying a clear and secure pathway or process for overcoming or correcting for this condition. It is also not about diffusing responsibility ad infinitum until we occupy a conceptual landscape where everyone's responsibility becomes no one's (see also Arendt cited in Rothberg, p. 46). Our goal is to understand ourselves as people who both genuinely desire justice and who also act as obstacles that impede its becoming. This produces a terrain of contradiction, paradox, and crisis because we are confronted - for real - with ethical and political complexity and, thus, with the impossibility of guaranteeing our goodness. Rather than expressing this crisis through the externalization of guilt and blame, we have the option to face the immanent contamination that has already ruined our chances.

This observation attracts us to what Michael Rothberg (2019) calls the implicated subject. This is a subject that cannot claim to be innocent, even in the case of - to return to Johnson $(1988$, p. 7$)$ - a lack of particular guilt. The implicated subject, writes Rothberg (p. 199), "both alludes to human beings located in a real, material world and serves as a trope for describing a contingent, shifting, and socially constituted position in the world." Importantly, he writes that "the implicated subject is not an identity, but a figure to think with and through" (p. 199). Rothberg's notion of implication is helpful for us here because it attempts to resist the need for innocence - indeed, its shifting ground cannot accommodate the frozen moral certitude that innocence requires. The implicated subject, therefore, offers a widened space for thinking about how we participate in complex social arrangements. As Rothberg puts it, the point is "not to dwell on or in implication but to transfigure it: to acknowledge and map implication in order to reopen political struggles beyond the defensive purity of selfcontained identities" (p. 201). This complicates our efforts at goodness in dramatic and difficult ways. To be implicated is to be - de facto - not innocent. Furthermore, there is no material or conceptual place to retreat from this implication. Thus:

degrees of implication pervade the social worlds of most inhabitants of the planet. Emphasizing the figural dimension of implicated subjects casts light on the diversity of figures of responsibility in critical discourse without reifying or essentializing differences and dynamic social relations. Indeed, implication comes in diverse forms: it describes beneficiaries and descendants, accomplices and perpetuators, and it can even attach to people who have had shattering experiences of trauma or victimization (p. 200).

It is important also to note that, here, too, the figure of implication does not promise either transparency or a more accurate parsing of culpability through more precise and detailed categorizations. The figure of the implicated subject represents "not a solution, but a problem" for thought (p. 200).

This starting point for theory acknowledges that we inhabit and reproduce machineries of violence, exploitation, and oppression, and that we move to distance ourselves from the recognition of this obvious and painful fact. For Rothberg, degrees of coercion are pertinent for thinking about responsibility, and some figures and occasions (like the Sonderkommandos) require a suspension of judgment. But for most of us, implication coheres in the "realm of conscious and unconscious consent" in the course of our everyday lives 
(p. 42). Here, Rothberg draws a distinction between guilt and responsibility. The notion of guilt is easily appended to and absorbed by liberal life, as it is attached to the actions of individuals; while responsibility offers a way of thinking about how we act collectively both for "good" and for "bad" (p. 48). This collectivity of responsibility implicates us regardless of our proximity to particular events or oppressions. For Iris Marion Young (in Rothberg, p. 50), guilt points backwards toward a crime that requires an agent's accountability, while responsibility looks toward transforming structural injustices as a future-oriented process. In this line of thought, we become responsible merely because we are involved in the world. Our humanity alone - social and political in its nature - is enough to implicate us. ${ }^{9}$ Furthermore, our crimes are not a deviation from an otherwise just order. Their ubiquity and universality gesture to the structural conditions that underpin their expression. The victim/perpetrator imaginary is thus an unhelpful ontological figuration. The forms of domination that are illuminated when we escape this binary implicate us in ways that cannot be hidden or dismissed through the normal pathways described above.

Loosening categories and binaries gives us space to embrace the contradictions that underpin our lives - to recognize the fact that we are actually inseparable from our violence (Kotef, 2020), from the pain we both inflict and endure in the replication of our globalized social orders. Neoliberalism most certainly produces otherness across its denuded terrain, but it does not have an outside which could offer a moral refuge for the good and the innocent.

\section{Questioning Innocence via the Encounter}

Against this backdrop of opacity and implication, we cannot offer a clear-cut solution to the challenge we identify. Part of this is because we also need something we might want to call the good. The locus of that "good," and how it might appear, are the subject of philosophical, historical, political, and theological debates that have unfolded in deeply complicated and inevitably power-mediated ways. The trouble we find is how visions of the good become an unassailable and unquestionable fetish around which attachments to innocence orbit, thus becoming servile to the expressions of power that cohere in the ways we have described.$^{10}$ Goodness is harnessed in and for its appearances; it salves our moral pain; it casts out those who cannot be absorbed or disciplined. Because goodness carries within it this inherent authoritarian quality, we cannot offer an easy fix to the conundrums it offers.

Speaking to the violent attachments of settler colonialism, heteronormativity, and white supremacy, Kotef writes, "I am not sure how one dismantles structures of desire [that sustain oppression]. I have seen people changing their mode of attachment to territories, landscapes, and others, especially through political activism, but not in ways that can become the foundation for a policy proposition" $(2020$, p. 23). We do not note this in order to retreat into some sort of requiem for justice, or to mourn its impossibility. We merely want to point out that the complexity of our attachments makes them intimate and sticky - inseparable from the constitution of the identities of both "oppressed" and "oppressor." Kotef does not really problematize the distinction between these, and yet still finds a deep web of institutional, structural, and psychological complicity that makes analysis toward solutions difficult.

Instead of looking for a world without innocence (Ticktin, 2017) we hope to understand more deeply how our attachments to it are already troubled and challenged. For us, this requires an excavation of how we are inserted into social relations as the oppressors. We do not mean here merely that we benefit from oppression - a point that we have tried to make above and which we do not consider to be particularly controversial but rather that we are the oppressors, and that oppression is intermingled with desire and even enjoyment (Foucault, 1988).

This takes us into a different terrain than the one Rothberg seems to traverse, and perhaps appears hyperbolic at first. ${ }^{11}$ Indeed, this is something more than implication. We observe that our need to identify and codify violence everywhere else but in ourselves and our own enterprises serves an important role in exonerating us, or in assuring that we never undertake the deep examination of our own violent attachments. Furthermore, in the externalization of violence and in the refusal to acknowledge its depths in ourselves, we actively participate in the creation of the monstrosities whose humanity must be put in doubt so that ours can be secured. The war

"Pascal said that my place in the sun is the image and the beginning of the usurpation of the whole earth. It is as if, by the fact of being there, I deprived someone of his vital space, as if I expelled or assassinated someone." Quoted in "Is it Righteous to Be? Interviews with Emmanuel Levinas" (Levinas, 2011, p. 128).

10 Alphonso Lingis writes that "the fetish is a caricature...that is put forth in the service of one's fears or one's cupidity" (46).

11 Not so much of a hyperbole in comparison to the following passage by Michel Foucault about fascism which, in his account, refers to "non seulement le fascisme historique de Hitler et de Mussolini-qui a su si bien mobiliser et utiliser le désir des masses-mais aussi le fascisme qui est en nous tous, qui hante nos esprits et nos conduites quotidiennes, le fascisme qui nous fait aimer le pouvoir, désirer cette chose même qui nous domine et nous exploite [not only the historical fascism of Hitler and Mussolini - which knew so well how to mobilize and use the desire of the masses - but also the fascism that is in all of us and haunts our minds and daily behavior, the fascism that makes us love power and desire that very thing that dominates and exploits us]" (Foucault, 1988, p. 50). 
criminal is one such figure (Dauphinee, 2008; 2013). So is the pedophile or sexual abuser (Ravecca, 2019). In the inability to see our violence as inherent to what we are, we become perpetrators of goodness, creating monsters who cannot be engaged but only rejected, corrected, and vilified. Hatred and disgust are cultivated as progressive virtues that police the boundaries by identifying the crimes as always outside and external. This is the movement that allows us to separate ourselves from the war criminals and the pedophiles. Through the abuse of the abuser, monstrosity - and damage - comes back to us (O'Shea, 2018).

This insight might also shed a particular needed light onto the dynamics of conventional politics. Consider the widespread sense among liberals in the United States ahead of the 2020 election that, if only the Democrats can retake control, things will get back to normal (read: be good again). We observe that Donald Trump and his supporters have had the effect of allowing liberals to evacuate their own contributions to the historical and ongoing structures of violence and oppression that characterize US society, and which have done so under the administrations of both parties. This erasure takes place through the creation of externalized monsters who can never be vulnerable, unsure, or in genuine need; through these moves, we conceal the monster in all of us. Progressives of different sorts - indeed not just liberals or Democrats - cultivate our hatred of the Donald Trumps of the world, waiting for their next outrageous move so that we can hate them more, and more exquisitely. In the meantime, we actively forget that those monstrosities are also happening very close to us, perhaps inside us, in the name of goodness. The devastating fall of Kabul in the first year of the Biden administration's tenure is a case in point.

We pause here to give space for the reader to balk. Scholarly forms do not allow us to fully consider what we are suggesting. When we approach the academic text, our defenses are already activated (Inayatullah, 2013; Ravecca \& Dauphinee, 2018). We can make only incremental, fully defensible moves, or else we risk attack, censure, and humiliation. The social costs of such risks are high for academics. This is one of the reasons why the university falls short as a site for intellectual risk or innovation. But this is also a function of the form in which we attempt to convey the message, rather than the difficult content of the message itself (see also Inayatullah, 2013, p. x). As critical theory is increasingly equated to morally charged indictments (of racism, homophobia, sexism and so on) against others, the response we expect is the immediate parsing and hierarchization of violence, and the separation of the self from the worst of the violence's implications: I benefit from settler colonialism, but I am not a genocidaire. I benefit from white supremacy, but I am not a racist. I have access to life preserving technologies while others die in modern camps, but I am not a eugenicist. I am fighting for my liberation, so I cannot be oppressing others.

Reading Butler and Berlant, Kotef writes that "violence emerges not as something that threatens identities but as what sustains them; in both, violence therefore also becomes an object of desire, or is at least woven into a desire for other objects" (Kotef, 2020, p. 17). We want to dwell in the following unbearable but, we think, important observation: goodness in public life is a comforting, if not gratifying, form of perpetration and we are its agents. We also want to dwell in another discomfort, and that is that we (always? often?) lack the reflexive capacity to see in our cures the ongoing perpetration of world-destroying violence (Clare, 2017; Dauphinee, 2016).

Our violent attachments furnish the mundane and the everyday. This makes them hardly visible for a gaze focused on spectacular monstrosities, but it does not make them less grievous. We inhabit a world of inequality and violence. And we also inflict this damage through our very enactments of innocence that conceal how deeply we are implicated in, and profit from, the harm done to others. Not surprisingly, those who embody the light of goodness are the ones building the gallows of history (Ravecca, 2019, p. 185).

Elsewhere (Ravecca \& Dauphinee, 2018), we have examined the promise of narrative forms of writing as vectors for challenging defensiveness and protecting complexity - things we think are necessary (though they are not guarantees) for a reflexive form of thought that locates the violence uncomfortably at home - that is, in our own attachments. Our hope for narrative approaches in scholarly and political life has been mainly fueled by our belief in their potential to accommodate, perform and embody complexity and ethical mobility, and to resist neat conclusions and indictments. Here, we also think that surprise is a key location in the intellectual work performed by the narrative voice. ${ }^{12}$ Reflecting on the distinctions between science and literature, Johnson (1988, p. 179) writes, "our response to literature is not like having something proved to us. It is more akin to being shown something which we did not previously see or understand." Crucially, it is in the literary form that "the world of the innocent, secure in its expectation that morality is stable and reliable, is left behind and is replaced by a realm of moral uncertainty and fragility" (p. 180). This recognition produces an inherent mobility in the landscape of moral and political engagements, showing how contradiction and paradox inhabit us.

This opens us to the reading that surprises the text - that announces failure and becomes an opportunity for the reader to open up what the text has enclosed. In this manner, narrative as a way of engaging both the personal and the collective can illuminate the complexities around the seductions of innocence. We share Johnson's point on how to think about failure in narrative. He writes, "if a particular narrative fails it is not

In the foreword to Politics of Exile, Naeem Inayatullah writes: "surprises emerge when we strike the balance between control and letting go... producing this surprise is the unconscious purpose of writing." (p. x). Enloe (2004) reflects on the role of surprise extensively. 
because some logical error has been made or an empirical mistake has been detected but because a deeper filling out of the story is required" (1988, p. 172). In political theory terms, we could say that a deeper exercise of reflexivity is necessary.

Our purpose here is not to revisit the potentialities of narrative as a resolution to the problem of innocence, but to deepen our understanding of how the potentials of narrative link with other sites of engagement toward the hope of something else - something that recognizes our own involvements in the deep damage and destruction that animates "the logic of the world" (Sosa Villada, 2016). Concretely, we want to theoretically engage with the encounter as a site where established scripts, particularly around the goodness of the self, can be challenged. While philosophy and science, at least in their mainstream articulations, tend to predetermine their rules of engagement with the encounter by offering categorizing silos that neatly host its different expressions, narrative forms seem more open to the multilayeredness, contradiction, and messiness that would allow us to suspend such judgement. The suspension of judgment, we want to stress, is critical for our ability to think and engage politically. ${ }^{13}$ The search for purity undermines creativity, intellectuality, and democratic dialogue. Our identification of the entanglements in and responsibilities for conditions of social violence is juxtaposed with the simultaneous need to suspend the judgment that indicts, precisely so that we can be confronted with the substance of our crimes and their interplays with others in the world.

Identifying in the encounter a response to the challenges of innocence might appear too abstract and generalizing on the one hand, or too concrete and specific on the other. But the encounter has been there all this time at our practical and conceptual disposal. Within the social sciences and elsewhere, we all work within encounters of different sorts. However, what we look for are the openness and plurality that are the possibility of every encounter. Our profession's obsession with knowing, controlling, and fixing is particularly obstructive here. The encounter does not occur outside of the structures that govern our lives more generally. It can be highly individualistic and self-aggrandizing. It can harm and destroy both others and ourselves. It can depoliticize. But it is also a site where the ungovernable flows of subjectivity and power emerge and can be seen (or, of course, remain unseen). It is important to note here that, as with Rothberg's implicated subject, the encounter is for us a problematique to think through, not a reified tool to be used in a pre-given manner. Encounters are the matter with which our political and social lives are made. Encounters' social location is mobile: they are both smaller and broader than politics in the sense that they happen in but also closer than and beyond the political system (Sartori, 1984) and the Habermasian public sphere. Therefore, they belong to the multi-scaled realm of the political (Menéndez-Carrión, 2015). Our interest in the encounter is not intended to deny the existence of structural oppression, or to suggest that systematic political failures to produce social goods like equality mean we should give up thinking about collectivity and justice. And even though in neoliberal societies they are routinely translated into "exchange value" and predictable, "one-dimensional" interactions with little space for ambiguity or surprise (Marcuse, 1991), and despite the fact that they are shaped by violence and by the very attachments to innocence we are trying to understand here, it is still the case that the indeterminacy of encounters overflows the (normative and/or analytical) metrics imposed on them. The potential for the generatively unexpected is always present, it is already occurring (Buck-Morss, 2010). The question is how we can grasp not only the "inconquerable difference between actuality and potentiality" explored by Marcuse (1991, p. 210) but also the multiplicity of versions, meanings, and facets of any encounter's actuality. ${ }^{14}$ In the one-dimensional world, the future is already decided (or at least measured and predicted).

We see in the encounter a site where different ways of being political might emerge. Encounters are indeterminate, fragile, and they can fail. But even where encounters appear to fail, they can also be transformative and potentiating. Even where preordained, the encounter's content of linguistic, material, and bodily interactions is prone to ambiguity, polyvalence, ungovernability, and transgression (Ravecca \& Dauphinee 2018). This announces a site of thought and action where the self and its available representations are potentially unfixed, and where this unfixity can serve as a freeing of the self even from the categories that are designed to liberate. Lingis writes (1994, p. 10): "the encounter begins with the one who exposes himself to the demands and contestation of the other." If we understand knowledge as formed through layers of contestation, then the opportunity to see ourselves unravelled by others seems to be a fruitful site of reflection. The encounter always threatens to dash our scripts. It announces an intrusion into our fixed realities. This intrusion challenges the selfsufficiency of our individual and collective projects and enterprises by introducing what cannot be absorbed or

\footnotetext{
Both of us have shown this in our respective scholarship in different ways, particularly in the context of abuse and violence. Ravecca (2019) shows that the relationship between the abused and the abuser is not usefully understood as a one-way transmission of intentioned oppression. He instead points out that the abused can also become the abuser. In Dauphinee (2013), the encounter with a war criminal becomes the site of a radical suspension of judgment that also indicts progressive politics and scholarship for its insistence on the facile distinction between innocence and guilt. See also Dauphinee (2008).

14 A lot is at stake in how encounters are read. Aiming at a pacified and just world Marcuse writes, "transcendence beyond the established conditions (of thought and action) presupposes transcendence within these conditions" (Marcuse 1991, p. 223). Marcuse theorizes the dialectical political status of poetry thus: "creating and moving in a medium which presents the absent, the poetic language is a language of cognition -but a cognition which subverts the positive. In its cognitive function, poetry performs the great task of thought: le travail qui fait vivre en nous ce qui n'existe pas (the effort which makes live in us that which does not exist) (Paul Valéry)" (Marcuse 1991, pp. 67-68). Our own turn to literature emphasizes more the challenge to attachments to innocence than its potential pathways to a global and future emancipated landscape.
} 
assimilated. As Lingis writes, "the community that produces something in common, that establishes truth and that now establishes a technological universe of simulacra, excludes the savages, the mystics, the psychotics - excludes their own utterances and their bodies. It excludes them in its own space: tortures" (Lingis 1994, 13). It is this exclusion which produces "society" -the exclusion of figures that are radically human- Lingis" psychotics, mystics, and savages -but also the war criminals and the pedophiles.

\section{Conclusion}

Rarely do we disclose our own evil. ${ }^{15}$ In Beyond Good and Evil, Friedrich Nietzsche writes that "the advocates of a criminal are seldom artists enough to turn the beautiful terribleness of the deed to the advantage of the doer" (Nietzsche, 1990, p. 97). The relationship between horror and beauty demands a deep reflection that cannot be accomplished here, as does the relationship between desire and violence. ${ }^{16}$ Nonetheless, we can posit that pleasure within our violent attachments is erased in our movements of (self) critique. Abuse, trauma, and desire meet in forms that we are obliged to hide. We are also obliged to hide how our yearnings for both vengeance and justice mesh within us. Thus, "introspection is a desperate need for both people and sciences" (Ravecca 2019, p. 182). It is here that we find the possibility of elaborating the horror we all carry, and which we reproduce in a multitude of settings - even those that promise or hope for liberation. This elaboration is crucial to the practices of de-reification and emancipation that have always been at the heart of critical theory.

Trying to face the horror that we carry is hard. It requires us to recognize the violence that always lurks in our attempts at liberation, how we participate in and benefit from the structures of oppression that we claim to be against, how we absolve our guilt by allowing ourselves to be purified by neoliberal rituals that leave power untouched and, most importantly, how innocence and goodness serve as shields to deflect critique. The recognition of these truths does not offer us a way out of their implications. Acknowledging them does not offer a blueprint for exoneration or exit. Our entanglement with oppression is ubiquitous. The operations of neoliberalism ensure this. Encounters can highlight and reinforce existing power arrangements, but they can also unravel and challenge the scripts. When we recognize that our goodness is also an inevitable violence, our certitude is shaken. We begin to see that, just as there is no objective place from which to judge the world, there is no place of innocence, either. Conceptualized in the way presented above, we hope that the encounter shakes our attachments to innocence thus opening further possibilities for scholarship and political dialogue.

\section{References}

Akhtar, Ayad (2020). Homeland elegies. A novel. Hachette Book Group.

Amadae, S.M (2015). Prisoners of reason: Game theory and neoliberal political economy. Cambridge University. https:// doi.org/10.1017/CBO9781107565258

Arendt, Hannah (1993). La condición humana [The human condition]. Paidós.

Arendt, Hannah (1995). De la historia a la acción [From history to action]. Paidós.

Bourdieu, Pierre (1988). Homo academicus (Peter Collier, Trad.). Stanford University.

Brown, Wendy (1995). States of injury: Power and freedom in late modernity. Princeton University.

Brown, Wendy (2015). Undoing the demos: Neoliberalism's stealth revolution. Zone Books.

Buck-Morss, Susan (2009). Hegel, Haiti and universal history. University of Pittsburgh.

Buck-Morss, Susan (2010). The second time as farce ... historical pragmatics and the untimely present. In C. Douzinas \& S. Žižek (Eds.), The idea of communism (pp. 67-80). Verso.

Butler, Judith (2004). Precarious life: The powers of mourning and violence. London: Verso.

Clare, Eli (2017). Brilliant imperfection. Grappling with cure. Duke University.

Dauphinee, Elizabeth (2008). War crimes and the ruin of law. Millennium, 37(1), 49-67. https://doi. org $/ 10.1177 / 0305829808093730$

Dauphinee, Elizabeth (2013). The politics of exile. Routledge.

Davis, Angela (2016). Freedom is a constant struggle: Ferguson, Palestine, and the foundations of a movement. Haymarket Books.

De Sade, Marquis (1996). Las 120 jornadas de Sodoma [The 120 days of Sodom]. Espiral.

15 There are notable exceptions: Tadeusz Borowski’s This Way for the Gas, Ladies and Gentlemen and Pierrepoint's autobiographical Executioner come to mind. There are also texts that glorify "evil," such as Junger's Storm of Steel.

16 Brett Ashley Kaplan (2007) examines the ethical implications of finding beauty in the horror of the Shoah; T. Nikki Cesare Schotzko's Learning How to Fall: Art and Culture After September 11 is a meditation on the World Trade Center's 9/11 jumpers and the intersections between political, traumatic, and aesthetically picturesque events. 
Enloe, Cynthia (2004). The curious feminist: Searching for women in a new age of empire. University of California. https://doi.org/10.1525/9780520938519

Eribon, Didier (2001). Reflexiones sobre la cuestión gay. Anagrama.

Foucault, Michel (1988). L'anti-oedipe: Une introduction a la vie non fasciste. Magazine Littéraire, 257 (September).

Foucault, Michel (1991). Historia de la sexualidad 1: La voluntad de saber. Siglo Veintiuno de España.

Giroux, Henry (2014). Neoliberalism's war on higher education. Haymarket Books.

Gramsci, Antonio (2008). Selections from the prison notebooks (Q. Hoare \& G. Nowell, Trans. \& Eds.). International Publishers.

Harvey, David (2005). A brief history of neoliberalism. Oxford University.

Horkheimer, Max (1978). Théorie critique. Payot.

Inayatullah, Naeem (2013). Foreword, in Elizabeth Dauphinee, The politics of exile. Routledge.

Johnson, Peter (1988). Politics, innocence, and the politics of goodness. Routledge.

Kaplan, Brett Ashley (2007). Unwanted beauty: Aesthetic pleasure in holocaust representation. University of Illinois.

Khan-Cullors, Patrisse and Bandele, Asha (2018). When they call you a terrorist. A black lives matter memoir. St. Martins's.

Kotef, Hagar (2020). Violent attachments. Political Theory, 48(1), 4-29. https://doi.org/10.1177/0090591719861714_

Kurowska, Xymena (2020). The secondary gains of neoliberal pain: The limits of consolation as a response to academic anguish. Political Anthropological Research on International Social Sciences 1, 26-45. https://doi. org/10.1163/25903276-bja10002

Levinas, Emmanuel (2001). Is it righteous to be? Interviews with Emmanuel Levinas (J. Robbins Ed.). Stanford University.

Lingis, Alphonso (1994). The community of those who have nothing in common. Indiana University.

Losurdo, Domenico (2011). Liberalism: A counter-history. Verso Books.

Marcuse, Hebert (1991). One-dimensional man: Studies in the ideology of advanced industrial society. Beacon.

Marx, Karl (1978). Economic and philosophic manuscripts of 1844. In R. C. Tucker (Ed.), The Marx-Engels Reader (pp. 66-125). Norton \& Company.

McNally, David (2011). Global slump. The economics and politics of crisis and resistance. Spectre.

Menéndez-Carrión, Amparo (2015). Memorias de ciudadanía: Los avatares de una polis golpeada. La experiencia uruguaya. Fin de Siglo.

Mohanty, Chandra Talpade (2013). Transnational crossings: On neoliberalism and radical critique. Signs 38(4): $967-91$. https://doi.org/10.1086/669576

Nicolacopoulus, Toula (2008). The radical critique of liberalism: In memory of a vision (anamnesis). re.press.

Nietzsche, Friedrich (1989). Genealogy of morals. Vintage Books.

Nietzsche, Friedrich (1990). Beyond good and evil. Penguin Books.

Nietzsche, Friedrich (2007). The Antichrist, Ecce Homo, Twilight of the Idols, and other writings (A. Ridley \& J. Norman, Eds.). Cambridge University.

O'Shea, Saoirse. C. (2019). My dysphoria blues: Or why I cannot write an autoethnography. Management Learning, 50(1), 38-49. https://doi.org/10.1177/1350507618791115

Ravecca, Paulo (2019). The politics of political science: Re-writing Latin American experiences. Routledge.

Ravecca, Paulo and Dauphinee, Elizabeth (2018). Narrative and the possibilities for scholarship. International Political Sociology, 12(2), 125-138. https://doi.org/10.1093/ips/olx029

Real de Azúa, Carlos (1973). La teoría política latinoamericana: Una actividad cuestionada. Retrieved from www. autoresdeluruguay.uy/biblioteca/Carlos_Real_De_Azua/lib/exe/fetch.php?media=teoriayetica.pdf

Rossello, Diego (2019). Politizando la ciencia política: Paulo Ravecca y el "yo disciplinar" de la ciencia política latinoamericana. Comentario a Paulo Ravecca, The Politics of Political Science: Re-Writing Latin American Experiences. EUNOMÍA. Revista en Cultura de la Legalidad,17,388-393. https://doi.org/10.20318/eunomia.2019.5043

Rothberg, Michael (2019). The implicated subject: Beyond victims and perpetrators. Stanford University.

Saad-Filho, Alfredo and Johnston, Deborah (Eds.) (2005). Neoliberalism: A Critical Reader. Pluto.

Sandel, Michael J. (2020). The tyranny of merit: What's become of the common good? Farrar, Straus and Giroux.

Sartori, Giovanni (1984). La política: Lógica y método en las ciencias sociales. Fondo de Cultura Económica.

Schotzko, T. Nikki Cesare (2014). Learning how to fall: Art and culture after september 11. Routledge.

Shepherd, Laura J. (2018). Activism in/and the academy: reflections on "social engagement." Journal of Narrative Politics, 5(1), 45-56.

Sky, Laura (2015). Canaries in the mine: filming women working in health care. In P. Armstrong and A. Pederson (Eds.), Women's Health: Intersections of Policy, Research, and Practice (pp. 344-357). Women's Press.

Slaughter, Sheila and Leslie, Larry (1997). Academic capitalism: Politics, policies and the entrepreneurial university. Johns Hopkins University Press.

Sosa Villada, Camila (2016). Pobres y estúpidos niños ricos. Retrieved from https://latinta.com.ar/2016/09/pobres-yestupidos-ninos-ricos/

Stahl, Titus (2013). What is immanent critique? Available at https://papers.ssrn.com/sol3/papers.cfm?abstract id=2357957

Ticktin, Miriam (2017). A world without innocence. American Ethnologist, 44(4), 577-590. https://doi.org/10.1111/ amet. 12558 
We Are Social and Hootsuite (2020). Digital 2020. July global statshot report. Available at: https://wearesocial.com/ blog/2020/07/more-than-half-of-the-people-on-earth-now-use-social-media

Wolgast, Elizabeth (1993). Innocence. Philosophy, 68(265), 297-307. https://doi.org/10.1017/s0031819100041231 